\title{
Biochemical Responses of Rice Varieties under Sodic Soil
}

\author{
Sanjay Kumar Tripathi*, A.H. Khan, Pradip Kumar Saini, \\ Mayank Pratap and Mayanker Singh
}

Department of Crop Physiology, Narendra Deva University of Agriculture and Technology, Narendra Nagar, (Kumarganj), Faizabad-224229 (Uttar Pradesh) India

*Corresponding author

\begin{abstract}
A B S T R A C T
Keywords

Salinity, Rice,

Chlorophyll, Proline,

Catalase, Sodium and

potassium

Article Info

Accepted:

06 May 2018

Available Online:

10 June 2018

The investigation entitled "Biochemical responses of rice varieties under sodic soil" was conducted during the kharif season in 2015 at the experimental site of Department of Crop Physiology at Narendra Deva University of Agriculture and Technology, Kumarganj, Faizabad-224 229 (U.P.) in randomized block design with three replications and eight varieties, four tolerant (CSR36, CSR43, Narendra Usar 3, NDR 2009) and four susceptible (Swarna sub 1, IR28, IR64, IR29). Evaluate the performance of tolerant varieties and susceptible varieties in sodic soil. Observations were recorded at 60, 90 DAT and maturity. Results indicate the biochemical characters such as chlorophyll content, proline content and catalase activity was increased in tolerant varieties and decrease in susceptible varieties. Tolerant varieties have less accumulation of sodium $\left(\mathrm{Na}^{+}\right.$and maintain better level of potassium $\left(\mathrm{K}^{-}\right)$under sodicity while, reverse is true for sensitive ones. CSR36 and CSR43 had a greater tolerance to sodic soil than IR64 and IR29.
\end{abstract}

\section{Introduction}

Rice is the monocarpic annual plant belonging to genus Oryza of Poaceae family. The genus Oryza has 24 species of which, 22 are wild and two species viz., Oryza sativa and Oryza glaberrima are cultivated. All varieties found in Asia, America and Europe belonging to Oryza sativa and varieties found in West Africa belonging to Oryza glaberrima, further Oryza sativa rice varieties of the world are commonly grouped into three sub species viz., Indica (India), Japonica (Japan) and Javanica (Indonesia). The largest rice cultivars are available at International Rice Research Institute (IRRI), Philippines, with over 100,
000 rice accession held in International Rice Gene Bank. "Rice is life" this slogan of the International year of rice (2004) outlines the importance of rice. Rice is a most important staple food crop in the world as well as in India. It is the rich source of energy and contains reassemble amount of protein 6-10\%, carbohydrate $70-80 \%$, mineral $1.2-2 \%$ and vitamins (Riboflavin, thiamine, niacin and vitamin E).

Rice is the most important staple food crop of millions of mankind from dawn of civilization. Among the cereal crops, it serves as the principal source of nourishment for over half of the global population that is why the 
rice production always holds a key role in the overall food situation of the whole world.

The global production of rice has been estimated to be at the level of 650 million tonnes and the area under rice cultivation is estimated at 156 million hectare. Asia is the leader in rice production accounting for about $90 \%$ of the world's production. Over $75 \%$ of the world supply is consumed by people in Asian countries and thus is of immense importance to food security of Asia.

Globally, India stands first in rice area and second in rice production, after China. It contributes about 40 to $43 \%$ of total food grain production and is playing a vital role in the food and livelihood security system.

Rice is cultivated world-wide over an area about 160.69 million ha $^{-1}$ with an annual production of about 478.76 million metric tonnes. In Indian agriculture; rice is the main source of livelihood for more than 150 million rural households. The total area of rice crop in India is 42.62 million hectare, production is 215.00 million tonnes and average productivity is $2.37 \mathrm{t} / \mathrm{ha}$ (Anonymous, 2014a).

Uttar Pradesh state is an important rice growing state in the country. The area and production of rice in this state is about 5.94 million hectare and 15.30 million tonnes respectively with an average productivity of 2.57 tonnes per hectare (Anonymous, 2014). About more than 800 million hectare of land through the world are salt affected. Among south Asian countries, India has the largest area (6.73 million ha). In India alone, 1.4 million ha are characterized by costal salinity, and inland alkaline (sodic) and saline soils (referred to as "usar" in the local dialect) cover about 5.33 million ha. Rice has previously been reported as being salt susceptible in the early seedling and reproductive stages, leading to yield reduction of more than $58 \%$ in crops exposed to $6.65 \mathrm{ds}$ $\mathrm{m}^{-1}$ EC. Salt affected soil often have multiple constraints including high $\mathrm{pH}$, high soluble salt, deficiency and toxicity of one or several micronutrients and poor water holding capacity, leading to low productivity. It causes a billion dollar losses in annual crop production globally.

Salt affected soils are identified by excessive levels of water-soluble salts especially sodium chloride $(\mathrm{NaCl})$. Excess $\mathrm{Na}^{+}$in plant cells directly damages membrane systems and abnormal development prior to plant death. The toxic ions cause ionic and osmotic stress at the cellular level in higher plants, especially in susceptible germplasm. Salinity reduces plant growth through osmotic effects and reduces the water uptake, thereby causing a reduction in growth. Salinity can limit plant growth and yield by three ways including reduce osmotic potential, ions toxicity creation, uptake disarrangement and balance of ions and cause disorder in enzyme activities membrane and metabolic activity in plant Murphy and Durako, 2003).

Rice is a salt-sensitive crop, yet it is the only cereal that can grow fairly well in salt-affected soils because of its ability to grow in standing water that can help leach salts from top soils to a level low enough for subsequent crops and also because it thrives during the rainy season in coastal saline areas where other crops cannot survive recurrent flooding.

\section{Materials and Methods}

The experiment was conducted in field under sodic soil with eight varieties CSR36, CSR43, Narendra Usar3, NDR 2009 (salt tolerant), Swarna sub1, IR64, IR28, IR29 (salt susceptible), thus the experiment consisted at a total of 8 treatment combinations. The whole experiment was planned under randomized block design with three replications. 
Nursery was raised in normal soil by sowing germinated seeds of all the 8 rice varieties on $1^{\text {st }}$ July 2015, which were taken for study. N P and K were applied in nursery@ 40:40:40 kg $\mathrm{ha}^{-1}$. Twenty five days old seedling of 8 varieties was transplanted in puddled plots with the spacing of $20 \times 10 \mathrm{~cm}$. Two seedlings were used for transplanting. Nitrogen, phosphorus and potash were added at the rate of 120,60 and $60 \mathrm{~kg} \mathrm{ha}^{-1}$, through urea, D.A.P. and murate of potash respectively. Half of the nitrogen, total phosphorus and total potash were added as a basal dose before transplanting. Remaining nitrogen was added in two equal split doses one at tillering stage and the other at the time of flowering.

The chlorophyll contents was estimated following the method of Arnon (1949) and expressed as mg per $\mathrm{g}$ fresh weight of leaves. Free proline content in leaves was estimated spectro-photometrically according to the methods of Bates et al., (1973). Catalase activity was assayed colorimetrically according to method given in analytical biochemistry (Sinha, 1972). The sodium and potassium content in leaves were determined by flame photometer.

\section{Results and Discussion}

The data pertaining chlorophyll content are presented in Table 1. It is clear that chlorophyll content progressively decreased with the increasing plant age. The tolerant varieties produced higher chlorophyll content as compared to susceptible varieties. The maximum chlorophyll content was recorded at 60 DAT in case of CSR36 (2.73 mg) followed by CSR43, Narendra Usar 3 and NDR 2009 and the minimum chlorophyll content was recorded in susceptible variety IR29 (2.00 $\mathrm{mg}$ ). Tolerant variety CSR 36 produced significantly higher chlorophyll content compared to all the susceptible varieties at all the stages of observations. Among all the susceptible varieties IR29 was found most susceptible while IR28 was recorded as least susceptible. Under saline condition there will be degradation in pigment, which induces decrease in chlorophyll content. Salinity stress may also led to destruction of fine structure of chloroplast and instability of pigment protein complex (Lapina and Papov, 1970). These results are corroborated with findings of Singh and Shrama (2010); Razzaque et al., (2010) and Jamil et al., (2012) in rice.

The data regarding proline content are presented in Table 2. The perusal of data reveals that proline content increased with the increase of plant age. All the tolerant varieties produced higher proline content as compared to susceptible varieties at all the stages of observations. However, the maximum proline content was recorded at 90 DAT in case of CSR36 (452 $\mu \mathrm{g})$ followed by CSR43, Narendra Usar 3 and NDR 2009 and the minimum proline content was recorded in IR29 $(376 \mu \mathrm{g})$. Tolerant varieties CSR36 and NDR 2009 produced significantly higher proline content as compared to all the susceptible varieties at all the stages of observations. Among all the susceptible varieties IR29 produced minimum while Swarna subl produced maximum.

The data regarding Catalase activity are presented in Table 3. The perusal of data reveals that catalase activity progressively increased with the increase of plant age. All the tolerant varieties produced higher catalase activity as compared to susceptible varieties at all the stages of observations. However, the maximum catalase activity was recorded at 90 DAT in case of CSR43 (579) followed by CSR36, Narendra Usar 3 and NDR 2009 and the minimum catalase activity was recorded in IR28 (440.0). Tolerant varieties CSR36 and CSR43 produced significantly higher catalase activity as compared to all the susceptible varieties at all the stages of observations. 
Table.1 Effect of sodicity on total chlorophyll content ( $\mathrm{mg} \mathrm{g}^{-1}$ fresh weight) in leaves in different rice varieties at various stages of rice

\begin{tabular}{|l|c|c|}
\hline Name of Variety & 60 DAT & 90 DAT \\
\hline CSR36 & 2.73 & 2.66 \\
\hline CSR43 & 2.62 & 2.33 \\
\hline Narendra Usar 3 & 2.57 & 2.26 \\
\hline NDR 2009 & 2.50 & 2.21 \\
\hline Swarna sub 1 & 2.43 & 1.86 \\
\hline IR28 & 2.25 & 1.98 \\
\hline IR64 & 2.12 & 1.76 \\
\hline IR29 & 2.00 & 1.59 \\
\hline SEm \pm & $\mathbf{0 . 0 1}$ & $\mathbf{0 . 0 1}$ \\
\hline CD at 5\% & $\mathbf{0 . 0 4}$ & $\mathbf{0 . 0 3}$ \\
\hline
\end{tabular}

Table.2 Effect of sodicity on proline content ( $\mu \mathrm{g} \mathrm{g}^{-1}$ fresh weight) in leaves of different varieties of rice at various growth stages

\begin{tabular}{|l|}
\hline Name of Variety \\
\hline CSR36 \\
\hline CSR43 \\
\hline Narendra Usar 3 \\
\hline NDR 2009 \\
\hline Swarna sub 1 \\
\hline IR28 \\
\hline IR64 \\
\hline IR29 \\
\hline SEm \pm \\
\hline CD at 5\% \\
\hline
\end{tabular}

\begin{tabular}{|c|c|}
\hline 60 DAT & 90 DAT \\
\hline 398 & 452 \\
\hline 392 & 448 \\
\hline 388 & 440 \\
\hline 384 & 434 \\
\hline 364 & 394 \\
\hline 360 & 394 \\
\hline 353 & 388 \\
\hline 339 & 376 \\
\hline $\mathbf{1 . 4 2}$ & $\mathbf{1 . 4 2}$ \\
\hline $\mathbf{4 . 3 0}$ & $\mathbf{4 . 3 1}$ \\
\hline
\end{tabular}

Table.3 Effect of sodicity on catalase activity (units $\mathrm{g}^{-1}$ fresh weight minute ${ }^{-1}$ ) in leaves of different varieties of rice at various growth stages

\begin{tabular}{|l|}
\hline Name of variety \\
\hline CSR36 \\
\hline CSR43 \\
\hline Narendra Usar 3 \\
\hline NDR 2009 \\
\hline Swarna sub 1 \\
\hline IR28 \\
\hline IR64 \\
\hline IR29 \\
\hline SEm \pm \\
\hline CD at $5 \%$ \\
\hline
\end{tabular}

\begin{tabular}{|c|c|}
\hline 60 DAT & 90 DAT \\
\hline 479.0 & 579.0 \\
\hline 493.0 & 589.3 \\
\hline 484.0 & 572.0 \\
\hline 462.0 & 561.3 \\
\hline 374.0 & 458.0 \\
\hline 352.0 & 440.0 \\
\hline 384.0 & 486.0 \\
\hline 356.7 & 446.7 \\
\hline $\mathbf{1 . 4 9}$ & $\mathbf{1 . 4 3}$ \\
\hline $\mathbf{4 . 5 1}$ & $\mathbf{4 . 3 5}$ \\
\hline
\end{tabular}


Table.4 Effect of sodicity on sodium content ( $\mathrm{mg} \mathrm{g}^{-1}$ dry weight) in leaves of different varieties of rice at various growth stages

\begin{tabular}{|l|}
\hline Name of Variety \\
\hline CSR36 \\
\hline CSR43 \\
\hline Narendra Usar 3 \\
\hline NDR 2009 \\
\hline Swarna sub 1 \\
\hline IR28 \\
\hline IR64 \\
\hline IR29 \\
\hline SEm \pm \\
\hline CD at $5 \%$ \\
\hline
\end{tabular}

\begin{tabular}{|c|c|c|}
\hline 60 DAT & 90 DAT & Maturity \\
\hline 1.40 & 1.37 & 1.31 \\
\hline 1.57 & 1.53 & 1.51 \\
\hline 1.73 & 1.68 & 1.63 \\
\hline 1.94 & 1.87 & 1.83 \\
\hline 2.11 & 2.02 & 1.97 \\
\hline 2.51 & 2.45 & 2.39 \\
\hline 2.72 & 2.68 & 2.63 \\
\hline 2.82 & 2.75 & 2.69 \\
\hline $\mathbf{0 . 0 1}$ & $\mathbf{0 . 0 2}$ & $\mathbf{0 . 0 2}$ \\
\hline $\mathbf{0 . 0 4}$ & $\mathbf{0 . 0 6}$ & $\mathbf{0 . 0 5}$ \\
\hline
\end{tabular}

Table.5 Effect of sodicity on potassium content ( $\mathrm{mg} \mathrm{g}^{-1}$ dry weight) in leaves of different varieties of rice at various growth stages

\begin{tabular}{|l|}
\hline Name of Variety \\
\hline CSR36 \\
\hline CSR43 \\
\hline Narendra Usar 3 \\
\hline NDR 2009 \\
\hline Swarna sub 1 \\
\hline IR28 \\
\hline IR64 \\
\hline IR29 \\
\hline SEm \pm \\
\hline CD at 5\% \\
\hline
\end{tabular}

\begin{tabular}{|c|c|c|}
\hline 60 DAT & 90 DAT & Maturity \\
\hline 2.02 & 1.96 & 1.69 \\
\hline 1.90 & 1.80 & 1.60 \\
\hline 1.84 & 1.78 & 1.57 \\
\hline 1.80 & 1.72 & 1.56 \\
\hline 1.75 & 1.66 & 1.47 \\
\hline 1.67 & 1.47 & 1.43 \\
\hline 1.57 & 1.39 & 1.31 \\
\hline 1.47 & 1.36 & 1.26 \\
\hline $\mathbf{0 . 0 1}$ & $\mathbf{0 . 0 2}$ & $\mathbf{0 . 0 2}$ \\
\hline $\mathbf{0 . 0 4}$ & $\mathbf{0 . 0 5}$ & $\mathbf{0 . 0 5}$ \\
\hline
\end{tabular}

Table.6 Effect of sodicity on $\mathrm{K}^{+} / \mathrm{Na}^{+}$ratio in leaves of different varieties of rice at various growth stages

\begin{tabular}{|l|c|c|c|}
\hline Name of Variety & 60 DA T & 90 DA T & Maturity \\
\hline CSR36 & 1.44 & 1.46 & 1.29 \\
\hline CSR43 & 1.21 & 1.18 & 1.08 \\
\hline Narendra Usar 3 & 1.07 & 1.06 & 0.96 \\
\hline NDR 2009 & 0.93 & 0.92 & 0.85 \\
\hline Swarna sub I & 0.83 & 0.82 & 0.74 \\
\hline IR28 & 0.67 & 0.60 & 0.60 \\
\hline IR64 & 0.58 & 0.52 & 0.50 \\
\hline IR29 & 0.52 & 0.49 & 0.47 \\
\hline SEm \pm & $\mathbf{0 . 0 1}$ & $\mathbf{0 . 0 2}$ & $\mathbf{0 . 0 2}$ \\
\hline CD at 5\% & $\mathbf{0 . 0 3}$ & $\mathbf{0 . 0 5}$ & $\mathbf{0 . 0 5}$ \\
\hline
\end{tabular}


Among all the susceptible varieties, minimum catalase activity was recorded in IR28 while maximum in Swarna sub 1. Antioxidant enzyme plays a significant role in plants to protect them against the damaging effect to ROS generated during salinity stress (Asada, 1992). SOD catalyses, the dismutation of superoxide to $\mathrm{H}_{2} \mathrm{O}_{2}$, which is detoxified by CAT and/ or POX to water and oxygen. These results are in accordance with the findings of Lin and Kao, 2000; Abdel Latef, 2010 and Chunthaburee et al., 2015 in rice under salinity stress.

The data pertaining to sodium content are presented in Table 4. It is clear from the data that all the tolerant varieties absorbed less sodium as compared to susceptible varieties at all the stages of observation. All the susceptible varieties absorbed significantly higher sodium in leaves as compared to all the tolerant varieties. Among all the susceptible varieties, maximum sodium content was recorded in IR29 followed by IR64, IR28 and Swarna sub 1. Among all the tolerant varieties, minimum sodium content was recorded in CSR43 followed by CSR36, Narendra Usar 3 and NDR 2009 at all the stages of observation. Enhanced uptake of sodium and decreased uptake of potassium and calcium under salinity stress have been also reported by Srivastava and Velu (2000).

An increased absorption of potassium and calcium is needed to maintain good Na-K balance for the growth of the plant in sodic soil. $\mathrm{Na}^{+}$specific damage is associated with accumulation of $\mathrm{Na}^{+}$in leaf tissues and results in necrosis of older leaves. Deficiency of other nutrients in the soil is due to the high concentration of $\mathrm{Na}^{+}$that interacts with other environmental factors, which exacerbate the problem (Pandey and Srivastava (1987). Besides, high $\mathrm{Na}^{+}$hampers the uptake of other nutrients, thus the uptake of water, growth limiting nutrients.
It is evident from the data presented in Table 5 , that tolerant rice varieties maintained high potassium content at all the stages of observation as compared to susceptible varieties. All the tolerant varieties absorbed significantly higher potassium content in leaves as compared to all the susceptible varieties. Among all the tolerant varieties, maximum potassium content was recorded in CSR36 followed by CSR43, Narendra Usar 3 and NDR 2009. Among all the susceptible varieties, minimum potassium content was recorded in IR29 followed by IR64, IR28 and Swarna sub 1 at all the stages of observation.

The perusal of data presented in Table 6. All the tolerant varieties maintained higher $\mathrm{K} / \mathrm{Na}$ ratio as compared to susceptible varieties at all the stages of observation. At 60 DAT and maturity maximum $\mathrm{K} / \mathrm{Na}$ ratio was recorded with variety CSR36 followed by CSR43, Narendra Usar 3 and NDR 2009. However, at 90 DAT CSR36 showed higher $\mathrm{K} / \mathrm{Na}$ ratio followed by CSR43, Narendra Usar 3 and NDR 2009. Among all the susceptible varieties, minimum $\mathrm{K} / \mathrm{Na}$ ratio was observed with variety IR64 followed by IR28, Swarna sub 1, IR29 at all the growth stages.

\section{References}

Abdel Latef, A. A. (2010). Changes of antioxidative enzymes in salinity tolerance among different wheat cultivars. Cereal research communication, 38: 43-55.

Asada, K. (1992). Ascorbate peroxidase, hydrogen peroxidase scavenging enzyme in plants. Plant Physiology., 55: 235-241.

Chunthabureea, S., Dongsansukb, A., Sanitchonb, J., Wattana Pattanagula, Piyada Theerakulpisuta, (2015). Physiological and biochemical parameters for evaluation and 
alleviation of Salt Stress in Rice by Seed Horti Agrobo., 42(2):405-413.

Lapina, L. and Popov, A. B. (1970). Effect of sodium chloride and photosynthetic apparatus of tomatoes. Plant Physiol., 17: 447-481.

Lin, C. C. and Kao, C. H. (2001). Cell wall peroxidase activity, hydrogen peroxidase level and $\mathrm{NaCl}$-inhibited root growth of rice seedlings. Plant Soil., 230: 135-143.

Murphy, K. S. and Durako, M. J. (2003). Physiological effects of short-term salinity changes on Ruppiamaritima. Aquatic Botany., 75: 293- 309.

Pandey, U. K. and Srivastva, R. D. L. (1987). Effect of salinity on calcium and sodium content in rice. Ind. J. Agric. Biochem., 6: 41-45.
Razzaque, M. A., Talukdar, N. M., Roy, T. S., Haranuzzaman, Mirza, and Bhadra, A. K. (2010). Salinity stress effect on biological changes in leaves of rice genotypes differing in salt tolerance. Recent research in Sciences and Technology, 2 (1): 40-46.

Shingh, Dhananjaya and Sharma, P. C. (2010). Effect of $\mathrm{NaCl}$ stress on photosynthesis characteristics and antioxidant enzymes in rice cultivars. Indian J. Plant Physiol., 15, (3) pp. 225258.

Srivastava, G. C., Zeng, L. and Velu, G. (2000). Status of sodium, potassium as a basis of salinity tolerance in rice. Ind. $J$. Plant Physiol., 5 (3): 300-302.

\section{How to cite this article:}

Sanjay Kumar Tripathi, A.H. Khan, Pradip Kumar Saini, Mayank Pratap and Mayanker Singh. 2018. Biochemical Responses of Rice Varieties under Sodic Soil. Int.J.Curr.Microbiol.App.Sci. 7(06): 1198-1204. doi: https://doi.org/10.20546/ijcmas.2018.706.142 